http://dx.doi.org/10.18232/20073496.1

Artigos

\title{
Marinha mercante chilena 1973-1985: a disputa entre economistas liberais e militares nacionalistas
}

\section{Merchant Marine Chilean 1973-1985: The Dispute between Liberal Economists and Nationalist Military}

\author{
Alcides Goularti Filho ${ }^{1, *}$ (D) 0000-0002-0808-4486 \\ ${ }^{1}$ Programa de Pós-graduação em Desenvolvimento Socioeconômico, Universidade do Extremo Sul Catarinense, Brasil. \\ * Correspondencia: alcides@unesc.net
}

Resumo. O objetivo deste texto é discutir o debate que ocorreu no Chile em 1973 sobre os rumos da marinha mercante: mantê-la estatal ou privatizá-la. Esse debate se deu entre uma ala dos militares chilenos que ainda defendiam o nacionalismo econômico e os economistas liberais (conhecidos como Chicago Boys) que assumiram o comando das reformas econômicas. A posição dessa ala nacionalista podemos acompanhar em alguns artigos publicados nas revistas Memorial del Ejército de Chile e Revista de Marina, e as bases ideológicas das reformas liberais estão expressas no documento El ladrillo, ou Programa de Desarrollo Económico, de 1973. Além desse debate, o texto também traz uma breve introdução sobre o nacionalismo econômico e contextualiza a trajetória da industrialização chilena e o desempenho do setor naval até o ano de 1973.

Palavras-chave: naval; nacionalismo; neoliberalismo; Chile.

Abstract. The purpose of this text is to discuss the debate that took place in Chile in 1973 about the direction of the merchant navy: to keep them state-owned or to privatize them. This debate took place between a wing of the Chilean military who still defended economic nationalism and the liberal economists (known

CÓMO CITAR: Goularti, A. (2021). Marinha mercante chilena 1973-1985: a disputa entre economistas liberais e militares nacionalistas. América Latina en la Historia Económica, 28(3), 1-24. DOI: 10.18232/20073496.1 
as the Chicago Boys) who took charge of economic reforms. The position of this nationalist wing can be followed in some articles published in the magazines Memorial del Ejército de Chile and Revista de Marina, and the ideological bases of liberal reforms are expressed in the document El ladrillo, or Programa de Desarrollo Económico, of 1973. In addition to this debate, the text also provides a brief introduction to economic nationalism and contextualizes the trajectory of Chilean industrialization and the performance of the naval sector until 1973.

Key words: naval; nationalism; neoliberalism; Chile.

JEL: N16; N76.

Recebido: 21 de agosto de 2020

Aceito: 04 de abril de 2021

Publicado: 13 de julho de 2021

Patrocinio: Pesquisa financiada pelo CNPq.

\section{INTRODUÇÃO: NACIONALISMO E LIBERALISMO ECONÔMICO}

Conceitualizar nacionalismo e o liberalismo econômico nos remete a um conjunto de definições de diversas ordens que assumem características diferenciadas no tempo e no espaço. Segundo Hobsbawm (1990), o conceito de nação, do qual derivou a defesa do nacionalismo, começou a ser mais utilizado, inclusive nas Enciclopédias, a partir dos meados do século xIx, sobretudo no bojo das revoluções liberais, superando a retórica de defesa apenas do território e da tributação. A defesa do ideal de nação fez parte dos inflamados discursos liberais, que se opunham ao internacionalismo do movimento operário. A nação unificada em torno de objetivos comuns, com a convergência de interesses, dentro das aspirações burguesas, traria benefícios econômicos e sociais a todos os cidadãos. Vamos encontrar na obra do prussiano Georg F. List (1986 [1841]), uma defesa da economia nacional em oposição aos interesses privados. Ao contrário de Adam Smith, que advogava a favor do individualismo e do universalismo, para List uma nação se constrói a partir de um coeso sistema de transportes e comunicação associado ao fortalecimento do mercado interno, protegendo as indústrias nascentes e criando benefícios e incentivos aos empresários nacionais (List, 1986). Os argumentos de List, em larga medida, estavam fundados nas ideias de Alexandre Hamilton, secretário de Tesouro dos Estados Unidos entre 1789 e 1795, que definiu um conjunto de políticas necessárias ao fortalecimento da economia nacional dos Estados Unidos (Hamilton, 1995). Hamilton e List eram adeptos do protecionismo como política central para o fortalecimento do mercado interno e da indústria nascente.

Mas será com a primeira guerra mundial (1914-1918) que o nacionalismo infla e assume um caráter bélico, identitário e excludente aos de fora. A exacerbação das flamulas nacionais na Europa, pós-1918, resultou em conflitos catastróficos e em genocídios. No pós-1945, depois de exorcizar o terror dos símbolos nacionais, o nacionalismo assume outras afeições e chega ao terceiro mundo amparado em movimentos sociais e de liberação colonial. No campo econômico, principalmente nos países que iniciavam seus processos de industrialização, o nacionalismo se converte em sinônimo de proteção do mercado interno, ampliação das funções produtivas das empresas estatais, criação de um sistema de crédito para o fomento da economia privada e amparo ao empresariado nacional com a intensão de formar oligopólios competitivos no mercado interno (ampliação da 
demanda doméstica) e externo (exportação de manufaturados). Será nesse caminho que a Comissão Econômica para América Latina e Caribe (CEPAL) irá trilhar, por meio de assessorias à diversos governos latinos na formulação de planos de desenvolvimento (Bielschowsky, 2000).

Se na Europa o nacionalismo deixou marcas da xenofobia, na América Latina ele ganhou dimensões social-reformista e modernizante, e na África de libertação do julgo colonial. No entanto, na América Latina, os resultados obtidos pelo nacionalismo sempre estiveram associados à ideologia das elites dirigentes que comandavam a estrutura do Estado. No seio do Estado, são condensadas as contradições sociais e estabelecidos os espaços de enfretamento e de avanços na disputa entre as diversas frações de classe (Poulantzas, 1985). Nesse sentido, enquanto uma ideologia, o nacionalismo perpassou por governos de direita, esquerda e militar. No âmbito das políticas comandadas pela direita, o nacionalismo econômico (proteção do mercado interno, alargamento das funções das estatais, crédito público e incentivo ao capital privado nacional) concentrou mais a renda, negligenciou as questões sociais e não alterou a estrutura agrária. Os governos de esquerda (ou centro-esquerda e de caráter popular), conduziram em paralelo a defesa do nacionalismo econômico, as reformas sociais e o fortalecimento das instituições democráticas. Os militares de tradição nacionalista também impulsionaram a industrialização, aliando-se ao empresariado nacional, fortalecendo os sistemas de transporte, comunicação e energia por meio de investimentos nas estatais e fomentando a formação dos oligopólios competitivos. Porém, com base na segurança nacional, criaram regimes autoritários com supressão de garantias individuais e aumento da repressão, que resultaram no aumento das desigualdades sociais e no dilaceramento das instituições democráticas.

Podemos pensar o liberalismo sob dois pontos de vistas: o político e o econômico. O liberalismo político está relacionado ao fortalecimento e consolidação da democracia representativa e das instituições balizares de uma sociedade fundada nos contratos sociais, segundo Jean Jaques Rousseau. Na esfera política, o liberalismo também pode ser associado a um conjunto de valores éticos e morais alicerçado no individualismo ontológico que permite o sujeito fazer suas escolhas pautada em seus princípios. Como face da mesma moeda, esse individualismo -sem as devidas amarras da civilidade- pode nos remeter a exacerbação da meritocracia e da superioridade do sujeito. Portanto, as modernas sociedades que protegem e valorizam suas instituições democráticas e garante as liberdades individuais pactuadas são herdeiras do liberalismo político (Bobbio, 2000).

O liberalismo econômico tem como linha mestra a crítica à intervenção exacerbada do Estado na economia e a defesa dos agentes privados na condução dos negócios rentáveis orientados pela lógica do mercado. O mercado deixa de ser apenas o locus da realização das trocas, dos contratos mercantis e da formação do preço para assumir uma forma superior de condição da vida econômica e social. Com base na tradição smithiana as funções do soberano deveriam estar delimitadas na manutenção da segurança e da justiça, além de outras atividades essenciais para facilitar o comércio, com a construção de estradas, pontes, canais navegáveis e portos. De David Ricardo, o liberalismo econômico herdou seus valores pautados no livre cambismo e nas vantagens comparativas do comércio internacional. O protecionismo, que Hamilton havia defendido em 1791 nos Estados Unidos, será criticado por Ricardo em 1817, que demonstrou as benesses do livre comércio para a comunidade internacional. Em Ricardo também podemos buscar os argumentos teórico que criticam a tributação sobre a renda nacional e a pressão que a mesma faz sobre os lucros, cujo resultado final, caso a tributação seja excessiva, será um menor crescimento da produção global. 
Se olharmos para as principais economias europeias dos séculos XVIII e XIX, diante do absolutismo e da sociedade de corte parasita, o liberalismo político e econômico constituíam-se como ideias inovadoras e revolucionárias. A aristocracia francesa que vivia em torno de nobreza e da realeza de Luís XIV, que mantinha uma política tributária elevada, era a antítese da ideia do trabalho com fonte geradora da riqueza, como advogava Adam Smith. A implementação do liberalismo na economia e sociedade inglesa possibilitou o Império Britânico desfrutar de prosperidade econômica e estabilidade política sem precedentes na história europeia durante os séculos XVIII e XIX. No entanto, quando observamos os eventos históricos que permitiram a Inglaterra exercerem sua hegemonia no comércio internacional, nos deparamos com a utilização de mecanismos extraeconômicos (violência) para garantir o livre cambismo e a abertura de portos. A Guerra do Ópio (1839-1842), que obrigou a China abrir seus portos aos ingleses, e a invasão da Baia de Edo (Tóquio) pela frota do almirante Matthew Perry em 1853, que obrigou o Japão abrir seus portos aos Estados Unidos, são eventos pautados na violência que pavimentaram os caminhos para as companhias inglesas e estadunidenses realizarem seus negócios. O mesmo fez o Japão em 1876, quando obrigou o Império de Joseon (Coreia) a assinar o Tratado de Kanghwa, abrindo o mercado coreano aos investimentos japoneses. O livre cambismo chegou no extremo oriente por meio da "diplomacia da canhoneira" e da assinatura de tratados desiguais.

O objetivo deste texto é discutir o debate que ocorreu no Chile após o golpe militar de 11 de setembro de 1973, que derrubou o governo de Salvador Allende (1970-1973) e impôs a sangrenta ditadura militar do general Augusto Pinochet (1973-1990), sobre os rumos da marinha mercante e da construção naval. Em 1973, ambas estavam estatizadas e a questão central seria: mantê-las estatais para fortalecê-las -como almejavam alguns militares da tradição nacionalistaou privatizá-las, entregando-as ao capital, seja ele nacional ou externo, como defendiam os civis que assumiram as reformas estruturais da economia chilena. Esse debate pode ser acompanhado em artigos publicados por militares nas revistas do exército (Memorial del Ejército de Chile) e da marinha (Revista de Marina) entre os anos de 1973 e $1985 .^{1}$

\section{UMA INDUSTRIALIZAÇÃO FRUSTRADA}

O Chile, na década de 1970, viveu a sua era dos extremos. Na política, o governo da Unidad Popular (1970-1973) ampliou a participação das camadas populares nas tomadas de decisões estratégicas do Chile por meio da radicalização da democracia; e na economia, foram aprofundadas as reformas econômicas que vinham sendo esboçadas há décadas, com o alargamento das funções do Estado na economia e na sociedade. A partir de 1973, foi implantado no Chile um programa liberal na economia, que reestruturou a sua base produtiva e entregou parte dos serviços públicos ao setor privado. Na cultura, a nova canção chilena de Violeta Parra e Victor Jarra foi suplantada pelos ritmos dos "embalos dos sábados à noite", o cinema de Patrício Guzmán e Miguel Littín foi silenciado e os poemas de Pablo Neruda se tornam subversivos. Esse extremo atingiu diretamente e indiretamente a vida dos 9.5 milhões de habitantes que viviam no Chile, da Terra do Fogo ao deserto do Atacama, nos anos de 1970.

\footnotetext{
${ }^{1}$ Ambas as revistas foram acessadas e digitalizadas durante a pesquisa realizada no arquivo do Museo Marítimo Nacional, em Valparaiso, Chile, no Instituto de Estudios Internacionales de la Universidad de Chile e na Biblioteca Nacional, em Santigo, durante o mês de setembro de 2015, que agora estão disponíveis on-line nos seguintes sítios: Memorial del Ejército de Chile (https://ejercito.cl/biblioteca/publicaciones-academicas/memorial-del-ejercito-de-chile) $e$ Revista de Marina (https://revistamarina.cl/ediciones/).
} 
A ruptura chilena do 11 de setembro, estava dentro do ciclo autoritário que assolou a América do Sul com a instituição de governos militares. No Brasil, os militares, pós-1964, aceleraram o processo de industrialização, financiando grandes complexos industriais e ampliando consideravelmente o número de estatais na economia, a qual havia sido gestada no governo de Getúlio Vargas (1930-1945, 1951-1954). Na Bolívia, os militares, pós-1964, mantiveram alguns pilares do setor produtivo estatal herdado da Revolução Nacional de 1952 com a nacionalização do petróleo em 1969. No Peru, os militares, mesmo inclinados à defesa da abertura econômica, evitaram que suas riquezas minerais fossem entregues às multinacionais norte-americanas com a nacionalização das reservas de petróleo, em 1968, que estavam nas mãos de companhias estrangeiras. Outro setor estratégico estatizado no Peru foi a indústria pesqueira, por meio da criação de uma empresa pública que passou a comandar a maior parte das atividades pesqueiras no País. Na Argentina, os diversos golpes pós-1955 até 1976, em boa medida, seguiram os fundamentos da industrialização nacional inaugurada durante o governo de Juan Domingo Perón (1946-1955).

Se, por um lado, o nacionalismo latino-americano obteve resultados com o fortalecimento das bases produtivas e a proteção dos setores estratégicos da economia, por meio da criação de empresas estatais e a defesa dos oligopólios nacionais, por outro, não foi bem-sucedido na gestão macroeconômica. A instabilidade dos preços - com situações beirando à hiperinflação -, os desequilíbrios nas contas públicas e a desvalorização acentuada do câmbio eram a tríade que atrapalhava o bom desempenho das políticas de industrialização. Foram assim os governos de João Goulart, Arturo Frondizi e Salvador Allende, em que todos enfrentaram, por exemplo, a alta generalizada dos preços. Outro fator que dificultava a estabilidade macroeconômica era o crescente endividamento externo, que a partir do final dos anos de 1970 estrangulou as finanças públicas e resultou em uma crise fiscal e financeira dos estados latinos. Essa crise imobilizou o setor público, reduzindo a sua capacidade de promover novas políticas de industrialização. Esse cenário de instabilidade macroeconômica foi propício para pavimentar o caminho para a abertura econômica (comercial e financeira) e o ajuste fiscal dos anos de 1980 e 1990. A promessa de inflação baixa e acesso aos bens de consumo modernos empolgava setores da classe média e tinha o aval do mercado financeiro internacional (Cano, 2000).

O Chile, pós-1940, conviveu com estes dois movimentos: nacionalismo industrializante e instabilidade macroeconômica. Em curtos intervalos de tempo, governos menos intervencionistas promoveram ajustes fiscais, cambiais e monetários para alcançar a estabilidade (sobretudo dos preços). A antítese da estabilidade era a recessão e um breve arrefecimento na política industrial (Pinto, 2018). Mesmo tropeçando nas políticas de ajuste, Chile, até 1973, constituiu um setor produtivo estatal que foi determinante para a formação do seu sistema nacional de economia. Entre as empresas estatais criadas para impulsionar a indústria chilena destacam-se a Empresa Nacional de Electricidad (Endesa), em 1944; a Compañía de Acero del Pacífico (CAP), em 1946; a Empresa Nacional del Petróleo, em 1950; o Banco del Estado de Chile, em 1953; a Industria Azucarera Nacional (IANSA), em 1953; a Empresa Nacional de Minería (EnAmi), em 1960; e, por fim, a maior de todas, a Corporación Nacional del Cobre, em 1971.

O financiamento da expansão do setor produtivo estatal e privado no Chile, em larga medida, foi sustentado pela Corporación de Fomento de la Producción (CoRfo), criada em 1939. Além de ser acionista de empresas privadas e sócia majoritária de empresas encampadas, a maior atuação da CoRfo foi na gestão e no financiamento das grandes empresas estatais chilenas ligadas à indústria de base. No Chile, a CoRfo assumiu o papel de capital financeiro, à la Hilferding (1985), tal 
como a Nacional Financeira Sociedad Anónima (NAFISA), de 1934, assumiu no México; o Banco Nacional de Desarrollo (BANADE), de 1944, na Argentina, e o Banco Nacional de Desenvolvimento Econômico e Social (BNDEs), de 1952, no Brasil.

A construção das bases para a formação de um sistema industrial integrado estava em marcha no Chile até 1973, sobretudo com a constituição da indústria pesada e de mineração e a ampliação da estrutura logística (transporte, comunicações e energia). O Estado chileno estava no comando dessa marcha, politizando as relações econômicas, no entanto, com as reformas neoliberais implementadas pela ditadura, podemos afirmar que o Chile é um caso de uma industrialização frustrada (ver Pinto, 2018). O mesmo se repetiu na Argentina, após o golpe militar de 1976, quando o governo do general Jorge Rafael Videla (1976-1981) optou por não seguir adiante com o projeto de industrialização herdado do peronismo, resultando em uma "industrialização inconclusa" (ver Ferrer, 2008). Ao contrário dos militares chilenos e argentinos, que optaram por interromper o processo de industrialização, os militares brasileiros levaram-no adiante, fundado na doutrina de segurança nacional, a industrialização herdada de Getúlio Vargas, colocando o Brasil no rol das nações mais industrializadas do mundo.

\section{PersistÊNCIA DO PASSADO}

Com um litoral de $7367 \mathrm{~km}$, o mar sempre foi determinante para definir a integração do território e da economia chilena. A dificuldade na construção de estradas de rodagem e de ferrovias pelo interior e a ausência de rios navegáveis fizeram da navegação marítima o meio de transporte mais utilizado no Chile desde a sua colonização. Junto aos principais portos -Valparaiso (Zona Central), Antofagasta, Iquique e Arica (Norte), Talcahuano, Valdivia e Puerto Montt (Zona Sul) e Punta Arenas (Zona Austral) - desenvolveram-se diversas atividades ligadas à navegação marítima, com a construção de oficinas para realizar reparos nas embarcações que atracavam nos portos ou estaleiros que construíam navios de pequenos e médios portes.

Essa prisão ao mar fez do Chile uma importante nação marítima da América Latina. No século XIX, foram fundadas diversas companhias de navegação privadas que frequentavam os principais portos do Chile. Com destaque para a Compañía Sud Americana de Vapores (CSAv), fundada em 1872, que está em operação até o presente momento. Na primeira metade do século xx, entre as empresas de navegação que surgiram, ressalto a Compañía Chilena de Navegación Interoceánica (CCNI), criada em 1930 com base em Punta Arenas; a Sociedad Anónima de Navegación Petrolera (SonaP), fundada em 1943 pela Compañía de Petróleos de Chile, uma distribuidora de combustíveis chilena; a Empresa Marítima del Estado (EMPREMAR), de 1953, a estatal chilena de navegação; e, por fim, a Naviera Interoceangás Sociedad Anómina (NISA), de 1961, que surgiu como uma subsidiária da CCNI, e que em 1974 adquiriu a SonAP. Portanto, a CGNi formava um grupo que controlava a NISA e a SoNAP. Foram essas as principais companhias de navegação que ditaram os rumos do setor naval chileno das décadas de 1950, 1960, 1970 e 1980. Essas empresas atuaram diretamente nas tomadas de decisões das políticas públicas destinadas ao setor de navegação no Chile. A EMPREMAR, por ser estatal, naturalmente era acionada para colaborar na formulação de políticas que envolviam a navegação marítima. As demais grandes empresas eram ouvidas e colaboravam com o governo, dado o alto grau de relevância que tinham na condução do transporte de cabotagem do extremo sul ao extremo norte do Chile. 
Na construção naval, Valparaiso, Talcahuano, Valdivia e Punta Arena se consolidavam como os principais centros navais. Em Valparaiso, destacavam-se os diques flutuantes do Astillero Las Habas, do Astillero de Frederico Schoess e do Astillero de Harold Germer y Cía, além das inúmeras oficinas e casas comerciais que forneciam peças e equipamentos para o "complexo naval" da região. Em Talcahuano, operavam dois diques secos que recebiam embarcações de médio e grande porte. Em Punta Arenas, havia o estaleiro Sociedad Braun \& Blanchard, que era proprietário do Varadero Miraflores e do Talles Minerva. Em 1941, ambos foram vendidos para a CCNI, que passou a atender às demandas da própria companhia (Martinic, 1995; Munita, 1945; Varas, 1995).

Para iniciar esse processo de centralização vertical no setor naval produtivo, por meio do Decreto Supremo 59 (17 de julho de 1952), durante o governo de Gabriel González Videla, a marinha chilena expropriou todas as instalações do Varadero Miraflores e do Talles Minerva em Punta Arenas. O passo seguinte, no governo de Jorge Alessandri, foi dado por meio da promulgação da Lei 321 (6 de abril de 1960), que criou o Astilleros y Maestranzas de la Armada (Asmar), tendo como ponto de partida a planta industrial, em Punta Arenas, e os arsenais da marina, com suas instalações de dársenas, diques secos e flutuantes e oficinas. A criação da AsMAR, de propriedade da marinha chilena, inicialmente foi uma tentativa de criar uma indústria naval pesada para atender às demandas da marinha de guerra e mercante, porém a opção das Forças Armadas do Chile foi concentrar os esforços da AsMAR na construção e nos reparos de embarcações militares. Na trajetória de formação da ASMAR, foram incorporados os diques secos em Talcahuano e encampado o Astillero Las Habas em Valparaiso, transformando-se no maior estaleiro chileno, que visava dar autonomia à armada nacional (Martin, 2005).

No bojo de expropriação do Varadero Miraflores e do Talles Minerva, em 1952; da criação da Empremar, em 1953; e da formação da Asmar, em 1960, durante o governo de Carlos Ibañez, foi promulgada a Lei 12.041 (Chile. Gobierno, 26 de junho de 1956), que reforçou a proteção à cabotagem nacional e garantiu 50\% do comércio externo (exportação e importação) para companhias chilenas. Esse novo ordenamento jurídico tinha como objetivo, além de proteger o mercado interno, fomentar o crescimento da marinha mercante e estimular a construção naval.

O governo da Unidad Popular de Salvador Allende (1971-1973) herdou uma marinha mercante e uma indústria naval em expansão, que vinha sendo norteada pela Política Nacional de Transporte Marítimo (1965-1974) elaborada pela Oficina de Planificacíon Nacional (OdePlan) em 1964. A Política propunha aumentar a frota nacional mercante de 322000 toneladas de porte bruto (тРв), em 1961, para 480 000, em 1970 (Wood, 1969). A presença da CSAV, CCNI, SonAP, NISA e EMPREMAR na navegação e da ASMAR na construção naval formava uma sólida base material por onde deveria ser ampliado o setor naval chileno nas próximas décadas.

No programa básico de gobierno de la Unidad Popular, estava previsto que os transportes aéreo, ferroviário e marítimo seriam nacionalizados, pois, junto com energia, petróleo, gás, siderurgia, química pesada e papel e celulose, eram considerados atividades estratégicas para o desenvolvimento econômico e social do Chile (Unidad Popular, 1970). Em boa medida, as grandes empresas desse setor pertenciam ao Estado, no entanto, a intenção era alargar ainda mais as funções econômicas e produtivas dele. No transporte ferroviário, a Empresa de los Ferrocarriles del Estado, criada em 1884, controlava todo o setor. No aéreo, a Línea Aérea Nacional de Chile, criada em 1929, era a maior companhia do Chile, e, na marinha mercante, a EMPREMAR estava entre os maiores armadores chilenos. 
A promessa foi cumprida e o Estado, por meio da Corfo e da OdePlan, coordenou a ampla nacionalização e estatização de vários setores da economia, envolvendo 725 empresas. Foram estatizadas as seguintes companhias de navegação: CGNI, CSAV, Compañía Naviera Arauco, Empresa Marítima del Sur, Compañía Marítima Técnica e a Sociedad de Transporte Marítimo ChiloéAysén. E os seguintes estaleiros: Astilleros Ahrend, Astilleros del Norte e Astilleros Marco Chilena (Chile, 2004).

Com a ampliação da democracia popular e as medidas de estatização de amplos setores estratégicos da economia, desencadeou-se na sociedade chilena, por parte das forças conservadoras, uma série de manifestações que tinham como propósito desestabilizar o governo Allende. A instabilidade política rebatia na macroeconomia, que começou a apresentar resultados negativos. No primeiro ano do governo Allende, em 1971, o PIB teve um crescimento de 9.4\%, porém, nos anos seguintes, a queda foi de $-1.0 \%$ e iniciou o ano de 1973 com expectativas negativas, encerrando o ano em -5.0\%. A inflação passou de 22.1\%, em 1971, que estava na média histórica dos últimos seis anos, para 163.4\%, em 1972, e 508.1\%, em 1973. O déficit nominal do governo central passou de $-1.22 \%$ do PIB, em 1970, para $-7.98 \%$, em 1971, e $-12.74 \%$, em 1972. Por fim, o câmbio teve uma variação de $57.02 \%$, em 1972, e 468.93\%, em 1973. Outro fator que agravou a situação econômica do Chile foi a queda do preço do cobre no mercado internacional, que passou de 64.19 centavos de dólares a libra, em 1970, e após a estatização e a criação da Corporación Nacional del Cobre o preço caiu para 48.55 centavos a libra, porém a produção continuou crescendo. A rápida recuperação do preço nos anos de 1973 e 1974 foi efêmera, pois o "choque do cobre" ocorreu no ano de 1975, quando o preço caiu para 55.94 centavos de dólares a libra.

$\mathrm{Na}$ opinião dos economistas que faziam oposição às reformas sociais da Unidad Popular, o governo estava insistindo em tomar decisões que agravavam cada vez mais o quadro macroeconômico chileno. A desordem macroeconômica se associava à instabilidade política e social. O quadro macroeconômico não reverteu imediatamente pós-1973, excluindo o breve crescimento de $2.4 \%$ do PIB em 1974. As demais variáveis acima analisadas continuaram instáveis entre 1974 e 1976. Com destaque para a queda acentuada do PIB, em 1975, de $-12.9 \%$, uma inflação de $340.7 \%$ e uma variação cambial de 490.2\%. O curto crescimento do ano de 1974, impulsionado pelo aumento de $22.67 \%$ na produção de cobre, revelou-se pífio. Para a Junta de Governo, formada por militares que assumiram o comando do Palácio La Moneda, estabilizar a economia para evitar os racionamentos era condição necessária para a manutenção da ordem. O Ministério da Fazenda foi ocupado, inicialmente, pelo contra-almirante Tito Lorenzo Gotuzzo Borlando, que permaneceu no cargo até julho de 1974. A incapacidade dos militares de gerenciar a economia levou o general Augusto Pinochet a entregar a gestão da macroconjuntura econômica para os civis.

O Brasil servia de bom exemplo para os militares chilenos. Enquanto a economia chilena estava afundando em crise, o Brasil vivia o seu milagre econômico, com taxas de crescimento acima dos $10 \%$ ao ano, preços e câmbio relativamente estáveis. A gestação da macroeconomia no Brasil estava entregue aos civis, mas o comando das estatais mais estratégicas, que tinham alguma relação com a segurança nacional, estava subordinado diretamente aos militares. O setor naval brasileiro era o mais robusto da América Latina, com a presença de grandes armadores estatais -Companhia de Navegação Lloyd Brasileiro, Docenave (Companhia Vale do Rio Doce) e a Frota Nacional de Petroleiros (Petrobras)- e privados -Companhia Libra de Navegação, Empresa de Navegação Mercantil e Frota Oceânica Brasileira. Entre os principias estaleiros, destacavam-se os de capital externo Ishibras (japonês) e Verolme (belga) e os estaleiros nacionais Mauá, Caneco e 
Emaq. Na primeira metade dos anos de 1970, estava em marcha no Brasil o I Plano Nacional de Desenvolvimento e, especificamente para o setor naval, o I Plano da Construção Naval, ambos obtendo resultados positivos (Goularti, 2014).

Além do Brasil, havia os exemplos da nacionalização de setores estratégicos no Peru e na Bolívia que haviam sido executados por militares. Também outras nacionalizações realizadas por civis, como no Equador, cujo governo do presidente José Maria Velasco Ibarra, em 1972, encampou todas as reservas e a estrutura produtiva e de comercialização do petróleo. Portanto, os militares chilenos nacionalistas que haviam apoiado a criação de estatais e a ampliação das funções da Corfo e da Odeplan, pré-1971, defendiam que os setores estratégicos da economia chilena deveriam ficar sob o comando do Estado.

Na Declaración de principios del gobierno de Chile, apresentada à nação pela Junta de Governo de 11 de março de 1974, estava expressa uma série de políticas que deveriam ser adotadas para restabelecer a normalidade política e social e retomar o crescimento econômico. Porém, atendendo ao apelo dos militares nacionalistas, foi definido que o Estado manteria em suas mãos os setores estratégicos e fundamentais para a nação:

Debemos concluir que a él [Estado] le corresponde asumir directamente sólo aquellas funciones que las sociedades intermedias o particulares no están en condiciones de cumplir adecuadamente, ya sea porque de suyo desbordan sus posibilidades (caso de la Defensa Nacional, las labores de Policía o las Relaciones Exteriores), o porque su importancia para la colectividad no aconseja dejar entregadas a grupos particulares restringidos (caso de los servicios o empresas estratégicas o fundamentales para la nación), o porque envuelven una coordinación general que por su naturaleza corresponde al Estado (Chile, 1974, p. 3).

Para a Marinha, o Chile era (e é) um país marítimo por naturez"e sua frota mercante, seus portos e seus estaleiros eram considerados fundamentais para a unidade e a integração do Chile, além de servirem de suporte básico para a segurança nacional. A indefinição das fronteiras com a Argentina na cordilheira dos Andes e no Canal de Beagle e a mal resolvida situação diplomática com a Bolívia, desde a Guerra do Pacífico (1879-1883), colocavam a Marinha de Guerra chilena em constante alerta. Portanto, não caberia repassar esses setores à iniciativa privada, visto que tomariam suas decisões apenas com base nos lucros. Ao contrário da Marinha, que se norteava na Doutrina de Segurança Nacional.

A divergência entre essas duas forças ideológicas nas Forças Armadas do Chile, uma de caráter mais liberal e outra mais nacionalista - porém, ambas eram anticomunistas- vinha se mantendo desde os anos de 1930, quando o Chile ingressou no processo de industrialização comandado pelo Estado. Durante o governo da Unidad Popular, essa dicotomia se esgarçou pelo fato de muitos militares terem aderido ao projeto de Allende (Valdivia, 2001). Após o 11 de setembro, o Corfo, que passou a ser comandada por militares até o final da década, mostrava alguma resistência em privatizar as empresas encampadas durante o governo Allende. Nos primeiros anos, foram entregues empresas ligadas aos setores menos importantes para dar sequência ao projeto de industrialização; no entanto, as indústrias e atividades de serviços (transportes, comunicações, energia) consideradas estratégicas, na avaliação da CoRfo, deveriam continuar nas mãos do Estado (Valdivia, 2001).

Essa tensão ideológica entre os militares acirrou-se com a entrada em cena dos economistas. Imediatamente após assumir o comando do executivo, Pinochet chamou em seu gabinete uma equipe de economistas da Pontifícia Universidade Católica do Chile, conhecidos como os 
Chicago Boys, para exporem suas ideias de reformas econômicas para retomar a estabilidade. Esses economistas, após passarem uma temporada na Universidade de Chicago, sob a orientação do professor Milton Friedman, do final dos anos de 1950 aos anos de 1960, retornaram ávidos para implementar suas ideias ultraliberais de reforma econômica. O ambiente de reformas sociais e intervencionismo estatal dos governos de Eduardo Frei (1964-1970) e Salvador Allende aguçava ainda mais os Chicago Boys, que se opunham veementemente ao desenvolvimentismo (Fontaine, 1988).

O primeiro esboço das reformas propostas pelos economistas foi apresentado ainda em 1970 ao candidato à presidência Jorge Alessandri, que não os recebeu com muito entusiasmo. Nos dois anos seguintes, os Chicago Boys, reunidos no Centro de Estudios Socioeconômicos, redigiram um documento que nortearia a política econômica e social do Chile nos anos da ditadura. Conhecido como El ladrillo, ou Programa de Desarrollo Económico (nome oficial do documento), foi apresentado à Junta de Governo nos dias seguintes ao 11 de setembro (Centro de Estudios Públicos, 1992).

O diagnóstico realizado pelos Chicago Boys sobre a economia chilena das últimas décadas era de que o baixo crescimento era resultado do excesso de estatismo, do atraso agrícola, da inflação e da escassez de empregos produtivos. Esses problemas estruturais resultaram em efeitos não desejáveis na economia, como má utilização dos recursos -limitando o desenvolvimento externo-, déficit fiscal e mal-uso do poder público. Definindo-se como um programa fundado em "criterio eminentemente técnico las alternativas de solución” (Centro de Estudios Públicos, 1992, p. 16), o Programa apresentava os seguintes objetivos: manter uma taxa de crescimento alto e estável, garantir igualdade nas oportunidades, promover a estabilidade das políticas macroeconômicas e, fundamentalmente, uma efetiva descentralização do sistema econômico. A descentralização era sinônimo de privatização.

Entre as políticas econômicas específicas, a descentralização se constituía na pedra angular do Programa. A proposta era que fosse feita uma radical privatização com a devolução das empresas estatizadas durante o governo da Unidad Popular, além de incluir as grandes estatais que atuavam em setores estratégicos da economia. A privatização deveria se estender também ao campo social, com a mercantilização da educação, saúde, assistência social e previdência, que deveria ser controlada pela iniciativa privada, a qual a manteria por meio da adesão dos trabalhadores aos serviços privados. O mercado seria o lugar ideal para alocação eficiente dos recursos escassos.

Para o setor externo, o Programa recomendava uma ampla abertura comercial e financeira, que previa a redução acentuada das alíquotas de importação. O ideal seria reduzir todas as alíquotas para zero para não favorecer nenhum tipo de atividade econômica. Porém os Chicago Boys admitiam "algun grado razonable de protección a los sustitutos de importación" (Centro de Estudios Públicos, 1992, p. 72) em torno de 30\%. Com relação aos investimentos diretos externos, deveriam facilitar o máximo possível a sua vinda para o Chile, sem criar privilégios em relação ao capital nacional, ou seja, igualdade para todos, o que evitaria o "peligro de la dependencia externa" (Centro de Estudios Públicos, 1992, p. 190).

A ascensão dos Chicago Boys no comando da economia chilena, a convite do general Pinochet, fez do Chile o primeiro laboratório para a implementação das reformas neoliberais. O Programa foi aplicado em duas fases. A primeira entre 1974 e 1981 e a segunda entre 1981 e 1989. No primeiro momento, foi a vez da abertura comercial e financeira, do forte ajuste fiscal, da reforma monetária (substituição do escudo pelo peso) e das privatizações das empresas que haviam sido encampadas no governo Allende. Os resultados dessas reformas promoveram um crescimento 
médio de PIB de 7.48\% ao ano, entre 1976 e 1981, redução dos déficits fiscais, queda acentuada da inflação (174.32\% em 1976 para 9.54\% em 1981) e estabilização cambial. O período foi denominado pelos neoliberais de milagre chileno, em referência ao milagre brasileiro que havia ocorrido no período anterior (1968-1973). Porém a crise dos anos de 1982 e 1983 fortaleceu os economistas que defendiam a necessidade de aprofundar as reformas neoliberais para retomar o crescimento e continuar com a estabilidade macroeconômica. Nos anos de 1980, na segunda fase, após a profunda recessão, foram privatizadas a previdência social, o sistema de saúde e a educação nos seus diversos níveis (Mayol e Ahumada, 2015) (ver tabela 1).

TABELA 1. DADOS CONJUNTURAIS DA ECONOMIA DO CHILE (1965-1989)

\begin{tabular}{|c|c|c|c|c|}
\hline Ano & PIB $(\%)$ & $\begin{array}{c}\text { Déficit público } \\
\text { nominal } \\
(\% \text { do } P I B)\end{array}$ & $\begin{array}{c}\text { Inflação } \\
(\text { IPC) }\end{array}$ & $\begin{array}{c}\text { Variação cambial } \\
\text { em relação ao ano } \\
\text { anterior }(\%)\end{array}$ \\
\hline 1965 & 0.95 & -1.64 & 25.83 & 31.86 \\
\hline 1966 & 11.24 & -1.88 & 16.96 & 26.48 \\
\hline 1967 & 3.62 & -0.64 & 21.89 & 27.20 \\
\hline 1968 & 3.59 & -0.79 & 27.94 & 34.89 \\
\hline 1969 & 3.94 & 0.60 & 29.34 & 32.24 \\
\hline 1970 & 1.83 & -1.22 & 34.93 & 28.72 \\
\hline 1971 & 9.42 & -7.98 & 22.13 & 7.42 \\
\hline 1972 & -1.02 & -12.74 & 163.43 & 57.02 \\
\hline 1973 & -5.03 & -7.32 & 508.05 & 468.63 \\
\hline 1974 & 2.38 & -5.79 & 375.88 & 650.84 \\
\hline 1975 & -12.91 & -0.41 & 340.70 & 490.26 \\
\hline 1976 & 3.83 & -0.48 & 174.32 & 165.84 \\
\hline 1977 & 10.44 & -1.11 & 63.49 & 64.97 \\
\hline 1978 & 7.40 & -0.11 & 30.32 & 46.99 \\
\hline 1979 & 8.42 & 4.82 & 38.90 & 17.66 \\
\hline 1980 & 7.99 & 5.41 & 31.24 & 4.71 \\
\hline 1981 & 6.53 & 2.56 & 9.54 & 0.0 \\
\hline 1982 & -11.01 & -1.02 & 20.73 & 30.53 \\
\hline 1983 & -5.02 & -2.67 & 23.09 & 54.77 \\
\hline 1984 & 4.10 & -2.95 & 23.04 & 24.99 \\
\hline 1985 & 4.01 & -2.22 & 26.42 & 63.35 \\
\hline 1986 & 5.38 & -0.92 & 17.36 & 19.94 \\
\hline 1987 & 6.46 & 2.36 & 21.45 & 13.72 \\
\hline 1988 & 7.35 & 4.07 & 12.68 & 11.67 \\
\hline 1989 & 9.92 & 5.31 & 21.41 & 8.96 \\
\hline
\end{tabular}

Fonte: Banco Central de Chile (2020). Disponível em https://si3.bcentral.cl/siete. Acesso em janeiro 2020. 


\section{RESISTÊNCIA NACIONALISTA}

As reformas neoliberais, sobretudo as privatizações dos setores considerados estratégicos para a economia, não foram bem recebidas por uma ala nacionalista das Fuerzas Armadas de Chile (Valdivia, 2001). Podemos acompanhar a resistência dos nacionalistas em artigos publicados em revistas do exército (Memorial del Ejército de Chile) e da Marinha (Revista de Marina) entre os anos de 1973 e 1985.

Em 1973, a marinha mercante chilena era composta de 53 navios, em um total de 518219 TPB, com uma frota mercante que atendia parcialmente ao transporte de longo curso, com destaque para a CSAV, a CGNI e a EMPREMAR, além da frota petroleira da SONAP. O transporte de cabotagem era exercido apenas por empresas nacionais. E, no setor de construção naval, os estaleiros estatais da ASMAR eram responsáveis por atender às demandas da Marinha, além de realizarem reparos para armadores privados. O setor naval estava em franca expansão desde os anos de 1960 e ampliou-se com as estatizações durante o governo da Unidad Popular. Na avaliação dos militares nacionalistas, necessitava se modernizar e ampliar ainda mais o seu caráter nacional para garantir a segurança do Chile.

O Decreto-Lei 466 (11 de junho de 1974) aprovou a nova política nacional de transporte marítimo e revogou a Lei 12.041 de 1956. A intenção dos neoliberais era abrir o máximo possível o longo curso e a cabotagem para empresas estrangeiras. Porém, na disputa entre nacionalistas e neoliberais, nesse decreto-lei, venceram os primeiros. No preâmbulo do decreto-lei há uma clara defesa à proteção da navegação e à indústria nacional: "Que toda la industria nacional, sin excepción, necesita en virtud de las dimensiones y desarrollo del mercado, de protección aduanera para quedar em situación competitiva frente a las industrias congéneres extranjeras, circunstancia a la cual no escapa la industria naviera" (Decreto-Lei 466, 11 de junho de 1974).

Os pilares das duas antigas leis de fomento à marinha mercante de 1922 e de 1956, a contragosto dos neoliberais, não foram removidos. Reforçaram a reserva de $50 \%$ destinada às embarcações nacionais no longo curso, de 75\% ao transporte de combustível e de $100 \%$ à cabotagem. Outra permanência que ficou com a nova lei foi a exigência de que a tripulação das embarcações deveria ser composta apenas por chilenos registrados na Dirección del Litoral y Marina Mercante. A mudança mais significativa do ponto de vista econômico foi a permissão para que empresas de capital externo pudessem participar em até $49 \%$ na composição acionária das companhias de navegação. Na lei anterior, o limite era de até $25 \%$.

A Revista de Marina publicou com certo entusiasmo sobre os pilares dessa nova política fundada no Decreto-Lei 466: “[...] asegurará un adecuado nivel de participación de la bandera nacional en prevención de situaciones o conflictos internacionales que puedan afectar los servicios marítimos normales" (Nueva política de transporte marítimo, 1974, p. 329). Entre os princípios da nova política, destaco os seguintes pontos: "En el concepto geopolítico de la nación, estos servicios [marina mercante] tienen una importancia estratégica de primer orden [...] La Marina Mercante Nacional deberá ser capaz de unir eficientemente por vía marítima todo el territorio nacional, asumiendo todo el transporte de cabotaje con énfasis particular en las zonas norte, austral e insular de nuestro país" (Nueva política de transporte marítimo, 1974, pp. 329-330).

No entanto, na queda de braço com os neoliberais, a marinha teve que ceder em alguns pontos, sobretudo no combate ao monopólio e na defesa da descentralização (privatização): "[...] Los transportes deberán operar y desarrollarse en un sistema de libre competencia, no aceptándose 
forma alguna de monopolio que pueda vulnerar la libertad de empresa o concurrencia al sector, ya sea por parte de los empresarios o de los trabajadores. [...] Las empresas estatales deberán ser descentralizadas (Nueva política de transporte marítimo, 1974, pp. 329-330).

Esse documento havia sido elaborado pelo Comité Coordinador Marítimo y Portuario, indicado pela Junta de Governo em setembro de 1973, composto, na sua maioria, por militares e pessoas ligadas ao setor privado de navegação, ou seja, sem a participação dos Chicago Boys. No entanto, incorporou marginalmente a ideia da descentralização do El Ladrillo.

A revista Memorial del Ejército de Chile, no mês de agosto de 1974, publicou um artigo do tenente-coronel Jose Julio Mazzeo, do exército argentino, o qual defende que a segurança nacional depende do desenvolvimento e da soberania nacional: "La política de Desarrollo lleva implícita una Política de Seguridad, sin la cual aquélla vería limitado el logro del bienestar y ésta no podría obtener un determinado poder sin la existencia de un grado adecuado de Desarrollo. [...] La seguridad y el desarrollo son interdependientes y se influencian recíprocamente. Ello a su vez lo realizan para con todos los otros planes de los diferentes niveles de la conducción nacional” (Mazzeo, 1974, pp. 159-160).

Para Mazzeo, os países em vias de desenvolvimento atingiram o pleno desenvolvimento quando ativaram todo o seu potencial nacional, o qual é condição necessária para preservar a soberania e a liberdade de um povo: "[l]os esfuerzos que la misma pueda requerir contribuyen innegablemente a la preservación de la soberanía nacional de un país y a la libertad del pueblo de esa nación." (Mazzeo, 1974, p. 161).

Na concepção dos militares nacionalistas do Chile, havia uma forte simbiose entre soberania, desenvolvimento, segurança e marinha mercante. Como seria possível manter a segurança sem uma marinha robusta, integrada e de caráter nacional? Nos discursos sobre a doutrina de segurança nacional, não havia espaço para a internacionalização dos setores estratégicos da economia.

No artigo do tenente-coronel W. Dorner (1974), temos uma defesa veemente dos pilares que formam uma nação na concepção militar: Estado, planejamento, segurança e desenvolvimento. Segundo Dorner (1974, p. 7), "[q]ualquer proyecto de cambio, que en su esencia debe contemplar la visualización futura del Desarrollo y la Seguridad Nacional, debe a nuestro juicio, tener como punto de partida el 'Interés Nacional', y ello porque, tanto la Seguridad como el Desarrollo del Estado, son en última instancia expresiones y necesidades dinámicas que es conveniente situar en un momento dado, conforme a la realidad objetiva imperante en nuestro país".

Para Dorner (1974), a planificação - uma política comum durante o governo de Allende- é um dos principais instrumentos que impulsiona todos os componentes e atividades de uma nação. E, em uma clara crítica aos economistas de Pinochet, que se colocavam acima de todos os interesses, declarando-se técnicos, Dorner alerta que os interesses individuais ou de grupos específicos não podem estar acima do interesse nacional, porque nem sempre há uma confluência de objetivos entre o indivíduo e a nação. O recado aos Chicago Boys foi o seguinte: "Normalmente en lo interno, hay grupos minoritarios económicos y sociales que confunden o identifican 'su interés' con el de la nación, subordinando a ellos el de esta, o más bien que presentan sus"intereses económicos"como si fueran los de la nación. En este caso el grupo dominante pretende ser el Estado"(Dorner, 1974, p. 9).

Em uma conferência realizada em junho de 1975 no Club de Leones, em Viña del Mar, o gerente administrativo Francisco Palet, da Compañia Chilena de Navegación Interoceánica (cCNI), que ainda era estatal, expressou sua opinião em relação ao setor privado naval, o qual corroborava com a ala nacionalista da marinha chilena. Segundo Palet (1975), dadas as características da 
marinha mercante, que estava subordinada às oscilações do comércio internacional, não seria recomendável deixá-la desprotegida. Em todos os países que dispunham de uma marinha mercante forte, de acordo com Palet, havia leis que a protegiam ou subsídios para manter suas atividades.

Em sua conferência, Palet apresentou uma proposta de política para ser aplicada ao setor naval, a qual chamou de "declaración específica de la política". Dentro do modelo, que na Declaración de principios definiu como "economia social de mercado", não seria permitido monopólios estatais ou privados, e o Estado deveria atuar de forma indireta, mas quando fosse necessário, de acordo com os objetivos superiores e vitais da nação, ele não hesitaria em intervir (Chile, 1974). Com relação às empresas estatais (EMPREMAR, ASMAR, CCNI e os portos), deveriam ser administradas de forma fragmentada "con el máximo de agilidad, eficiencia y productividad, eliminando sus déficit de operación” (Palet, 1975, p. 546).

Palet também defendia a ampliação da reserva de mercado no longo curso para os armadores chilenos, exigindo que eles exercessem suas funções com razoável competência. Além disso, reforçou que, quando necessário, o Estado poderia participar em até 49\% na composição do capital das companhias de navegação, conforme previsto no Decreto-Lei 466 de 1974, e ampliar a participação da bandeira nacional nas exportações de minerais. Para os estaleiros estatais, Palet defendia que deveriam ser realizados mais investimentos para proporcionar adequadas estruturas aos serviços destinados à marinha mercante.

Por fim, para fomentar a marinha mercante, Palet olhava para o Brasil e recomendava que fosse criado um fundo, nos moldes do Fundo da Marinha Mercante criado no Brasil em 1959, que financiasse a construção naval chilena:

Debería adoptarse una política aún más agresiva para fomentar la marina mercante, si se considerase que los impuestos que tienen todos los fletes fuesen a un fondo que se empicase únicamente en fomentar las actividades navieras. Ejemplo de ello nos ha dado Brasil, que en un plazo inferior a 15 años ha pasado a ser una de las potencias marítimas más grandes del mundo, tanto por el volumen de su flota como por el número de naves construidas en astilleros brasileños para todos países del mundo (Palet, 1975 , p. 550).

Portanto, percebe-se que havia uma estreita relação entre as propostas defendidas por Francisco Palet com as dos nacionalistas. Há de se ressaltar que ele estava administrando uma companhia de navegação estatizada durante o governo Allende, e que, a contragosto dos Chicago Boys, os militares mantiveram nas mãos do Estado até 1985.

Entre os dias 9 e 12 de dezembro de 1975, foi realizado na Faculdad de Ciencias Económicas da Universidad de Chile um seminário, com a presença de militares, economistas e acadêmicos, para debater as estratégias de desenvolvimento econômico para o Chile. No mesmo ano, o resumo desse seminário foi publicado no Memorial del Ejército de Chile, em janeiro de 1976, organizado pelo coronel Hector Barrera (1976). Recordo que em 1975 о PIB chileno teve uma queda acentuada de $-12.91 \%$, que deixou os militares nacionalistas céticos diante das reformas neoliberais.

Sobre o tema segurança nacional, o general Agustín Toro Dávila expressou sua preocupação se a rígida política de combate à inflação, com drásticos cortes orçamentários, poderia realmente promover um equilíbrio entre o programa econômico (neoliberal) e a segurança nacional. O general também defendia que o Estado deveria intervir na economia para induzir o desenvolvimento e sua relação com a geopolítica (ver Barrera, 1976, pp. 7-8). 
Pare reforçar a necessidade da intervenção estatal na economia, Hugo Trivelli Oyarzún, que havia sido ministro da agricultura do governo Eduardo Frei (1964-1970), expressou sua opinião afirmando:

El Estado debería tener en el futuro un papel activo en la conducción y en la materialización del desarrollo nacional. El debería ser actor principal en la definición de las grandes líneas de la estrategia de desarrollo del país [...] También resulta importante la tarea de promoción del desarrollo, en la cual el Estado podría participar prestando apoyo técnico y financiero al sector privado y por medio de inversiones directas, que se canalizarían fundamentalmente hacia la infraestructura, los sectores sociales y la explotación de recursos naturales, en especial los renovables (Barrera, 1976, pp. 10-11).

Outro tema debatido no seminário foi a relação entre o papel do mercado e a planificação da economia, exposta pelos professores neoliberais Alfonso Serrano Spoerer, Mario Gómez Puig e Andrés Passicot Callier. Após fazer um breve relato de que a agenda conjuntural havia se sobreposto sobre as estratégias de longo prazo, Spoerer e Callier defenderam que a intervenção do Estado se justificava apenas nos seguintes pontos: “[...] fijación de precios a productos esenciales; impuestos y prohibiciones a la importación de bienes suntuarios; fijación del tipo de cambio; fijación de la tasa de interés; creación artificial de empleos en el sector público y fijación de salarios mínimos y leyes de inamovilidad." (ver Barrera, 1976, p. 11).

Segundo os professores, em outro momento histórico do Chile, o Estado atuava nas atividades produtivas, na definição dos rumos da industrialização e no crescimento planejado de setores estratégicos. No entanto, o professor Callier concluiu que: “[...] un sistema económico organizado sobre la base de una acción predominante del mercado no excluye la posibilidad de utilizar algún mecanismo de planificación. Más que esto, ello aparece indispensable para orientar las decisiones en el mediano y largo plazo" (ver Barrera, 1976, pp. 11-12).

Essa tensão entre os economistas neoliberais e os militares nacionalistas deu uma arrefecida com a retomada do crescimento econômico pós-1975. A inflação iniciou uma trajetória de queda, o câmbio se estabilizou e o preço do cobre se recuperou no mercado internacional. Era o milagre chileno. Segundo Mayol e Ahumada (2015), essa retomada foi mantida com base no novo bloco de poder entre os militares e o capital financeiro. A abertura financeira permitiu a entrada de capitais especulativos, que ampliou a liquidez e possibilitou a sustentação do rápido crescimento, e o sistema bancário chileno foi internacionalizado. A abertura comercial, por meio da redução acentuada das alíquotas de importação, ampliou as atividades comerciais ligadas à classe média. O dilema da Junta de Governo era: recompor o crescimento com base nos fundamentos da industrialização, que ampliaria a classe operária e inevitavelmente resultaria no fortalecimento do seu poder de barganha ou fundar-se em um novo modelo previsto no El ladrillo, ou Programa de Desarrollo Económico. A segunda opção foi a vencedora, porém com a resistência de vários segmentos sociais.

Se, por um lado, a economia estava crescendo a $10 \%$ ao ano, por outro, as desigualdades sociais também aumentaram devido ao arrocho salarial e à repressão sindical. O aumento do PIB era concomitante ao aumento da repressão, da tortura, dos assassinatos políticos e dos exílios, ou seja, o sacrifício da democracia estava sendo compensado pelo crescimento econômico, mesmo que fosse excludente (ver tabela 2). 
TABELA 2. ECONOMIA DO COBRE E BALANÇA COMERCIAL (1965-1989)

\begin{tabular}{|c|c|c|c|c|c|}
\hline Ano & $\begin{array}{l}\text { Preço do cobre } \\
\text { no mercado } \\
\text { mundial }^{a}\end{array}$ & $\begin{array}{c}\text { Produção } \\
\text { de cobre } \\
\quad(\text { mil } t)\end{array}$ & $\begin{array}{c}\text { Exportações } \\
\text { total } \\
\text { (US\$ mi fob) }\end{array}$ & $\begin{array}{c}\text { Exportações } \\
\text { cobre } \\
\text { (US\$ mi fob) }\end{array}$ & $\begin{array}{c}\text { Importações } \\
\text { total }^{b}\end{array}$ \\
\hline 1965 & 58.73 & 584.50 & 684 & 429 & 616 \\
\hline 1966 & 69.47 & 625.40 & 866 & 599 & 775 \\
\hline 1967 & 51.13 & 660.20 & 874 & 651 & 769 \\
\hline 1968 & 56.10 & 657 & 911 & 684 & 802 \\
\hline 1969 & 66.56 & 688.10 & 1173 & 926 & 927 \\
\hline 1970 & 64.20 & 691.60 & 1112 & 840 & 956 \\
\hline 1971 & 49.27 & 708.30 & 999 & 701 & 1015 \\
\hline 1972 & 48.56 & 716.80 & 849 & 618 & 1103 \\
\hline 1973 & 80.78 & 735.40 & 1309 & 1049 & 1447 \\
\hline 1974 & 93.27 & 902.10 & 2151 & 1623 & 2016 \\
\hline 1975 & 55.94 & 828.30 & 1590 & 868 & 1708 \\
\hline 1976 & 63.61 & 1005.20 & 2116 & 1233 & 1655 \\
\hline 1977 & 59.29 & 1054.20 & 2186 & 1139 & 2417 \\
\hline 1978 & 61.89 & 1034.20 & 2460 & 1219 & 3243 \\
\hline 1979 & 89.83 & 1062.70 & 3835 & 1888 & 4708 \\
\hline 1980 & 99.17 & 1067.90 & 4705 & 2125 & 5469 \\
\hline 1981 & 78.95 & 1081.10 & 3837 & 1738 & 6513 \\
\hline 1982 & 67.06 & 1242.20 & 3706 & 1685 & 3643 \\
\hline 1983 & 72.17 & 1257.50 & 3831 & 1875 & 2845 \\
\hline 1984 & 62.45 & 1290.70 & 3651 & 1604 & 3288 \\
\hline 1985 & 64.28 & 1356.20 & 3804 & 1789 & 2920 \\
\hline 1986 & 62.29 & 1401.10 & 4191 & 1757 & 3099 \\
\hline 1987 & 81.09 & 1418.10 & 5303 & 2235 & 3994 \\
\hline 1988 & 117.94 & 1451 & 7054 & 3416 & 4844 \\
\hline 1989 & 129.11 & 1609.30 & 8078 & 4021 & 6595 \\
\hline
\end{tabular}

a Centavos US\$ por libra.

b cif 1965-1979 e fob 1980-1989 - US\$ mi.

Fontes: Banco Central do Chile (2020); Servicio Nacional de Geología y Minería (2016).

\section{APROFUNDAMENTO DAS REFORMAS NEOLIBERAIS}

A euforia do crescimento fortaleceu ainda mais a presença dos Chicago Boys no comando da economia e tinham todo aval de Pinochet. No entanto, para ele, as reformas caminhavam muito lentas e deveriam ser aceleradas. Faltava um choque para converter Pinochet no "Cesar neoliberal" e calar o que ainda restava dos militares nacionalistas. O passo mais adiante seriam as reformas sociais com a privatização da previdência e da assistência social (administradoras de fondos de pensiones), além de transformar em fundações, com autonomia financeira, as universidades e os hospitais. O esperado veio com a crise de 1982 e 1983, que levou à queda acentuada do PIB em - $11.01 \%$ e -5.02\%, respectivamente. A inflação voltou a acelerar, o câmbio reiniciou sua trajetória de desvalorização e 
o preço do cobre caiu no mercado internacional. Segundo Mayol e Ahumada (2015, p. 111), "[1]a crisis de 1982 marcó el temprano fin de un crecimiento insustentable em el mediano plazo [...] La salida de la crisis fue de la mano de un giro em la estrategia económica. Vía un amplio proceso de reestructuración de las más importantes instituciones económicas, el sector financiero pierde la hegemonía dentro del bloque de poder y se construye un bloque exportador dominante".

Nesse novo bloco de poder, o setor exportador, juntamente com as grandes multinacionais, assumiu o comando da acumulação. Sem diversificar a pauta de exportações nem substituir exportados, o Chile aprofundou suas especializações, fundadas na velha divisão internacional do trabalho: minérios (especialmente o cobre), madeira, frutas, pescados e vinhos.

Em meio à euforia do crescimento foi apresentada uma nova lei de fomento à marinha mercante. As principais mudanças que afetaram diretamente a marinha mercante chilena foram as seguintes:

Artículo $3^{\circ}$ - El cabotaje, entendiéndose por tal el transporte marítimo, fluvial y lacustre de carga entre los puertos del litoral y en los ríos y lagos cuyo origen y destino final sea un puerto de la República, queda reservado a las naves chilenas.

No obstante, lo anterior, los volúmenes de carga superiores a 5000 toneladas podrán ser licitados con la publicidad y anticipación debidas por los usuarios, con participación de navieros extranjeros, previa autorización del Ministerio de Transportes y Telecomunicaciones.

El transporte marítimo de las cargas de importación y exportación queda reservado en un $50 \%$ a las naves mercantes chilenas. Sin embargo, cuando algún país imponga a las naves chilenas reservas de carga en un porcentaje superior o inferior al $50 \%$ de la carga que origine, el porcentaje de reserva de carga que se aplicará en Chile a las naves provenientes de tal país se entenderá elevado o reducido al que ese país aplique a las naves chilenas sin perjuicio de lo que se previene en el inciso final de este artículo (Lei 3.059, 21 de dezembro de 1979).

A Lei 3.059 redirecionou a marinha mercante chilena, abrindo plenamente o seu mercado de cabotagem. Quando observamos a trajetória de crescimento do setor naval com base na TPв de 1965 a 1980, percebemos que há um crescimento constante, com aquisição de novas embarcações. A ditadura seguiu a tradição deixada por Eduardo Frei e Salvador Allende. A manutenção da CCNI, da CSAV e da Sociedad de Transporte Marítimo, sob o controle estatal (total ou parcial), e o protecionismo da cabotagem de $100 \%$ e do longo curso de $50 \%$ garantiriam um crescimento contínuo da frota mercante chilena. Coincidentemente ou não, a Lei 3.059 foi aprovada no momento em que se iniciou a nova fase de abertura comercial e de fomento às exportações.

Em seguida à promulgação da nova lei, a Revista de Marina publicou editoriais e artigos criticando a sobreposição dos interesses econômicos imediatos (lucro) sobre os interesses nacionais e a segurança nacional.

No editorial de março de 1980, a Revista retomou o seu argumento central: o Chile é um país essencialmente marítimo.

Ello se deriva de sus características geográficas, tanto de forma como de situación, de la enorme extensión de su territorio marítimo y de sus orientaciones económicas naturales, sean de producción o de comercio, pues ambas se sustentan en la vinculación 
internacional, que tiene como vía fundamental el medio marítimo. [...] Esta condición esencial no ha sido ni es claramente perceptible para la comunidad nacional (Los intereses marítimos, 1980, p. 101).

Fazendo referência à relação entre os interesses marítimos e nacionais, os quais são os pilares da segurança nacional, o editorial direcionou suas críticas à Lei 3.059:

Los intereses marítimos representan así al Interés nacional en su concepción más amplia porque, al cimentar sus actividades en las características más propias del patrimonio físico y cultural del país, impulsan racionalmente la Prosperidad nacional, y al disponer, junto con el Poder Naval que han ayudado a generar, de una plena capacidad para dominar en el mar, que es el escudo y el arco de Chile, contribuyen en alto grado a la Seguridad Nacional (Los intereses marítimos, 1980, p. 102).

Na publicação seguinte da mesma revista, as críticas foram mais contundentes após traçarem uma narrativa histórica entre a estreita relação do mar com a prosperidade de diversas civilizações. O editorial conclui que "la política de libre comercio exterior vigente lanza a exportadores e importadores tras el más bajo flete, sin importarles la nacionalidad de la nave, e impulsa a los armadores nacionales a buscar estrictamente la mayor utilidad, aunque ella se logre sobre naves de otras Banderas" (El transporte marítimo, 1980, p. 185).

Segundo esse editorial, os navios que navegavam pelos mares e rios chilenos deveriam ser preferencialmente de propriedade nacional "[d]eben ser nuestros buques los que, preferentemente, lleguen de manera segura a las distantes riberas que esperan tales bienes, quedando en nuestras manos no sólo el producto de ese servicio, sino la capacidad excedente para atender otras áreas de comunicación marítima" (El transporte marítimo, 1980, p. 186).

Por fim, o editorial concluiu que o destino do Chile sempre foi ser marítimo e que sua marinha era "demasiada fuerte para ser removida por pressiones pasajeras [...] conciencia marítima nacional está consolidando firmemente su visión de Chile como país marítimo, a pesar de los cantos de sirena que, por apegarnos excesivamente a la tierra y al beneficio inmediato, nos alejan del verdadero Toisón" (El transporte marítimo, 1980, p. 186).

Podemos deduzir que los cantos de sirena era o mantra dos Chicago Boys. E concluiu-se que o transporte marítimo era inseparável do destino nacional do Chile, um país com vocação para o mar.

As críticas continuaram nas revistas seguintes, em novembro de 1980, inclusive denunciando os irrefrenables apetites do capital externo, o qual tinha plena liberdade para atuar no longo curso e nas vantagens na cabotagem:

[...] el escaso desarrollo de esta ha influido decisivamente en la exigüidad de aquéllos, conformándose así un escaso aprovechamiento de ventajas tan singulares, cuya debida utilización fortalecería por sí sola nuestra posición internacional y sofocaría en su génesis los irrefrenables apetitos foráneos, que despierta y alimenta la contradictoria realidad de su importancia y su postergación (Política marítima nacional, 1980, p. 518).

Em defesa dos armadores nacionais que estavam sendo penalizados pela Lei 3.059 de 1979, o capitão de navio, Jorge Hadermann (1981) afirma que as companhias chilenas, diante da abertura, "no está en condiciones de competir adecuadamente en el mercado tarifario" (p. 404). A política 
de abertura, segundo Hadermann, poderia ser viável em tempo de paz, mas "qué pasaría ante el evento de un nuevo conflicto mundial en el cual Chile ni siquiera participe, declarándose neutral" (p. 405). Lembrando que no ano de 1978 acirrou a disputa entre o Chile e a Argentina pelas ilhas no Canal de Beagle, colocando em prontidão a marinha chilena. Por fim, Hadermann (1981) concluiu com o bordão da marinha: "Finalmente, cabe recordar que desarrollo y seguridad nacional son indivisibles y deben ser armónicos. Es un hecho que la marina mercante no afecta negativamente al desarrollo, sino que, por el contrario, contribuye a él. Por otra parte, [...], se desprende que una Marina Mercante Nacional es indispensable para la seguridad nacional” (p. 405).

Apelar para a indissociabilidade entre a marinha mercante e a segurança nacional era a estratégia utilizada pelos militares da marinha para tentar convencer Pinochet e seus aliados da área econômica que a abertura era uma opção equivocada e deletéria para o sistema nacional de economia.

Ao analisar os artigos da revista do exército (Memorial del Ejército de Chile), percebe-se claramente que as críticas ao modelo econômico neoliberal adotado pela ditadura foi reduzindo a partir da segunda metade da década de 1970. Pelo contrário, há artigos que tentaram buscar elementos que corroborassem a opção de Pinochet. O tenente-coronel Victor Fuentes (1982) classifica as reformas neoliberais como medidas correctivas, portanto, necessárias. Após fazer uma longa explanação dos aspectos econômicos da Declaración de Principios, Víctor Fuentes detalha as medidas. Destaco o ponto referente às privatizações, que atingia diretamente o setor naval estatizado:

El Estado, en su carácter de subsidiario, debe vender aquellas empresas que en manos de particulares pueden seguir existiendo. De esta forma, se produce el ingreso de dinero a las arcas fiscales y se puede paliar el déficit. Las medidas correctivas aplicadas tienen como finalidad principal mejorar el nivel del comercio exterior chileno, disminuir los ingresos en forma proporcional a la caída del producto geográfico bruto (lo que el país produce) y disminuir el desempleo existente (Fuentes, 1982, p. 73).

Esse pequeno fragmento revela as divergências existentes entre os nacionalistas que ainda restavam da Marinha e dos convertidos ao neoliberalismo do Exército. Segundo Garrido, Castagneto, Mesina e Rivera (2006, pp. 168-169):

El instrumento de la nueva política económica fue el Decreto Ley 3.059 de 1979, que, a decir verdad, no dejó de producir aprensiones en vísperas de su entrada en vigencia. No era tan fácil cambiar todo un modo de pensar orientado a la protección de nuestra marina comercial, más aún cuando a lo largo de prácticamente toda la historia del Chile republicano, la legislación que se fue dictando sobre el particular se centraba en medidas de cuidado y fomento de esta actividad, independientemente de que los resultados hubiesen sido los esperados. Por ello, los temores eran razonables, y era entendible la pregunta inquietante: ¿Sobrevivirían nuestros armadores a una competencia totalmente libre y desprotegida, en el vasto mercado marítimo internacional?

Garrido et al. (2006, p. 169) conclui que o Chile era o "un caso praticamente único em el mundo" que não estava protegendo a sua marinha mercante. O resultado dessa abertura foi imediato, com queda acentuada na frota de 1092274 тРв, em 1978, para 701187 тРв, em 1984, ou seja, uma redução de $35.79 \%$ em apenas seis anos. Sendo que nos seis anos anteriores à promulgação da nova lei (entre 1973 e 1978) houve um aumento de $52.55 \%$ na frota em toneladas de porte bruto (ver tabela 3 ). 
TABELA 3. EVOLUÇÃO DA FROTA MERCANTE DO CHILE (1965-1989)

\begin{tabular}{cc}
\cline { 2 - 2 } Ano & tpb \\
\cline { 2 - 2 } 1965 & 356000 \\
1966 & 340000 \\
1967 & 326000 \\
1968 & 317000 \\
1969 & 328000 \\
1970 & 468000 \\
1971 & 550000 \\
1972 & 518000 \\
1973 & 541000 \\
1974 & 686000 \\
1975 & 797000 \\
1976 & 846000 \\
1977 & 1092000 \\
1978 & 985000 \\
1979 & 997000 \\
1980 & 831820 \\
1981 & 972015 \\
1982 & 878964 \\
1983 & 768624 \\
1984 & 745899 \\
1985 & 731511 \\
1986 & 701776 \\
1987 & 907538 \\
1988 & 824869 \\
1989 & 912717 \\
\hline
\end{tabular}

Fontes: Naciones Unidas (2018); Asociación Nacional de Armadores (1989).

\section{REPARANDO ERROS}

Após a depressão pela qual passou a economia chilena entre 1982 e 1983, queda média do PIB de $8.02 \%$ em apenas dois anos, o discurso neoliberal ganhou força e convenceu os militares que comandavam a política do Chile. Se a economia havia se recuperado pós-1973 com a implementação parcial das reformas neoliberais, a segunda retomada viria somente com a ampliação das reformas, sobretudo com as privatizações das grandes empresas estatais que ainda estavam sendo preservadas. Agora era a vez da Empresa Nacional de Electricidad (ENDESA), da Industria Azucarera Nacional (IANSA), da Compañía de Acero del Pacífico (CAP), da Empresa Nacional de Telecomunicaciones (EnTEL), da Sociedad Chilena de Fertilizantes (Sochif) e de outras grandes empresas que formaram a base da truncada industrialização nacional. 


\section{TABELA 4. DEVOLUÇÕES, VENDA DE AÇÕES E PRIVATIZAÇÕES DO SETOR NAVAL CHILENO}

\begin{tabular}{lrrr}
\hline Empresa & Devolução & Venda de ações & Privatização \\
\hline Compañía Chilena de Navegación & & & \\
$\quad$ Interoceánica (CGNI) & - & - & 1985 \\
Compañía Sud Americana de Vapores & & & \\
$\quad$ (CSAv) & 1974 & $1981-1984$ & - \\
Compañía Naviera Arauco & 1974 & - & - \\
Compañía Marítima Técnica & 1974 & - & - \\
Sociedad de Transporte Marítimo & & - & 1986 \\
$\quad$ Chiloé-Aysén & - & - & - \\
Astilleros Ahrend & 1974 & - & - \\
Astilleros Marco Chilena & 1976 & - \\
\hline
\end{tabular}

Fonte: Gobierno, Chile (2005).

No setor naval ocorreu a venda do restante das ações da CSAv, em 1984, que ainda estavam nas mãos da CoRfo; a privatização da CCNI, em 1985, e da Sociedad de Transporte Marítimo Chiloé-Aysén, em 1986 (ver tabela 4).

No setor naval, após a queda acentuada na frota mercante do País e reclamações dos armadores e membros da Marinha, o governo cedeu às pressões e editou uma nova lei de fomento à marinha mercante nacional, que ajustou a Lei 3.059 (21 de dezembro de 1979). A Lei 18.454 (11 de novembro de 1985), corrigia alguns erros de 1979, porém sem retornar ao modelo protecionista de 1974 e 1956. Cedia de um lado, mas afrouxava de outro. Nos dois pontos mais polêmicos (proteção à cabotagem e longo curso) houve mudanças. Com relação à cabotagem, na lei de 1979 as companhias estrangeiras poderiam participar quando a carga excedesse 5000 toneladas. Na nova lei de 1985, o valor foi reduzido para 900 toneladas. Porém, ficou definido que "[e]n este caso, y para el solo efecto de la adjudicación de la licitación, las ofertas con naves extranjeras se incrementarán en un porcentaje similar al de la tasa general del arancel aduanero, de acuerdo con el procedimiento que señale el Reglamento" (Lei 18.454, 11 de novembro de 1985).

Essa cobrança de uma "tarifa aduaneira" compensava a redução da tonelagem permitida para as companhias estrangeiras. A outra mudança que ocorreu foi em relação ao longo curso, que não alterou o percentual garantido dos navios chilenos, porém introduziu o princípio da reciprocidade: "Para los efectos de transportar los cargamentos que se conducen por la vía marítima desde o hacia Chile, se aplicará el principio de reciprocidad, de tal forma que la proporción del acceso que tendrán las naves extranjeras a las cargas marítimas, desde o hacia el país, se regulará según la proporción del acceso que, en sus tráficos correspondientes, se permita a las naves chilenas por el país respectivo" (Lei 18.454, 11 de novembro de 1985).

Segundo Garrido et al. (2006, p. 172) “[e]sta nueva modificación a la normativa sobre marina mercante venía así a corregir una política económica demasiado apegada a la ortodoxia teórica, para introducir elementos de mayor flexibilidad, que se adaptaban a la realidad del tráfico marítimo internacional”. 
Nos anos seguintes à promulgação da nova lei até o fim da ditadura Pinochet, em 1989, a economia chilena seguiu uma trajetória de crescimento econômico -entre 1986 e 1989 o PIB cresceu em média 7.28\% ao ano- e estabilidade cambial e fiscal com a queda na inflação. Destacase também a recuperação acentuada do preço do cobre no mercado internacional, que chegou a ser vendido a 129.11 centavos de dólar a libra em 1989, o dobro de 1985.

No setor naval, em função da nova lei e do aumento constante do comércio externo, motivado pela abertura comercial e pelo aumento da produção de cobre, ocorreu uma recuperação em uma expansão da frota mercante. Em 1985, a frota mercante chilena era de 731511 тPв e encerrou a década em 912717 TPB, um aumento de $24.77 \%$. Um resultado muito positivo se compararmos com a queda de $35.79 \%$ entre os anos posteriores à promulgação da lei de 1979 .

\section{CONSIDERAÇÕES FINAIS}

A escolha de um projeto de desenvolvimento pautado no nacionalismo ou no liberalismo econômico não se resume apenas na opção por um autor clássico da economia. O nacionalismo promove a industrialização e a ampliação do mercado interno, porém seus excessos podem trazer descontentamento sociais e desencadear numa crise política-institucional com repercussões macroeconômicas. O mesmo podemos pensar em relação à implementação de políticas liberais (ou neoliberais) em países que ainda apresentam altos índices de desigualdades sociais, cujo resultados podem promover uma estabilidade macroeconômica sem distribuição dos ganhos sociais. No entanto, quando ambos, nacionalismo e liberalismo, estão associados à regimes autoritários os resultados são perversos para a ampla maioria da sociedade. A história recente da América Latina, pós-1945, revela que a combinação entre nacionalismo, liberalismo e autoritarismo reforçaram o caráter desigual da economia e da sociedade.

Até o final dos anos de 1960, o Chile seguiu o modelo de industrialização fundado no modelo estruturalista-cepalino, também seguido por outros países vizinhos, como proteção do mercado interno, criação de estatais em setores estratégicos onde havia inércia empresarial, liberação de crédito público e benefícios ao capital nacional. Durante o governo da Unidad Popular (1970-1973), houve um maior alargamento das funções do Estado, entrando em setores tradicionalmente controlados pela iniciativa privada. Pós-1973, com a ascensão no comando da política econômica dos Chicagos Boys, foi criado um empasse entre a ala militar, que defendia a manutenção das estatais nos setores estratégicos, e os jovens economistas, que defendiam um programa de reforma econômica que incluía a ampla privatização dos serviços e das atividades produtivas, comerciais e logísticas. Especificamente no setor naval, os militares nacionalistas defendiam a manutenção da marinha mercante e da construção naval nas mãos do Estado por questões de segurança nacional. Os Chicagos Boys visavam apenas à eficiência e à produtividade. Com os resultados positivos de alguns indicadores econômicos, sobretudo a retomada do crescimento e o controle da inflação e do déficit público, os economistas ganharam respaldo do general Pinochet e impuseram os princípios do El ladrillo também no setor naval. Mesmo com resistência, as reformas neoliberais também chegaram para a marinha mercante, no entanto mantiveram nas mãos da Marinha os estaleiros estatizados da Asmar.

O alargamento das reformas neoliberais nos anos de 1980 não conseguiu afastar todas as resistências herdadas do passado industrializante, mesmo assim impôs um programa de privatização que colocou nas mãos da iniciativa privada (nacional e estrangeira) diversos setores estratégicos da economia. No entanto, além dos três estaleiros, manteve-se nas mãos de Estado a gigante 
Corporación Nacional del Cobre, a Empresa Nacional del Petróleo, a Corfo e a Empresa de los Ferrocarriles del Estado. Foi nos serviços sociais que a privatização mais avançou (saúde, educação, previdência e assistência), fazendo do Chile um bom exemplo de uma macroeconomia estável e eficiente, porém com aumento das desigualdades sociais e com perdas na soberania econômica. O elemento diferenciador que permite mais desenvolvimento e justiça social é a democracia associada a um conjunto de políticas públicas distributivas.

\section{REFERÊNCIAS}

Asociación Nacional de Armadores (1986). Valparaíso y los armadores chilenos (Segunda parte). Revista Marina, 3, 1-23.

Banco Central de Chile (2020). Base de datos estadísticos. Recuperado de https://si3.bcentral.cl/

Barrera, H. (1976). Semanario: Estrategias de desarollo para Chile. Memorial del Ejército de Chile, $68(387)$.

Bielschowsky, R. (org.). (2000). Cinquenta anos de pensamento na CEPAL: uma resenha. In Cinqüenta anos de pensamento na (vol. 1). Rio de Janeiro: Record.

Bobbio, N. (2000). Liberalismo y democracia. México: Fondo de Cultura Económica.

Cano, W. (2000). Soberania e política econômica na América Latina. São Paulo: Universidade Estadual Paulista/Universidad de Campiñas.

Centro de Estudios Públicos (1992). El Ladrillo: Bases de la política económica del gobierno militar chileno. Santiado: Autor. Recuperado de https://www.cepchile.cl/cep/

Chile. Gobierno (1952, julho 17). Decreto Supremo 59. Recuperado de https://www.leychile.cl/

Chile. Gobierno (1956, junho 26). Lei 12.041. Recuperado de https://www.leychile.cl/

Chile. Gobierno (1974a). Declaración de principios del gobierno de Chile. Santiago: Autor.

Chile. Gobierno (1974b, junho 11). Decreto-lei 466. Recuperado de https://www.leychile.cl/

Chile. Gobierno (1979, dezembro 21). Lei 3.059. Recuperado de https://www.leychile.cl/

Chile. Gobierno (1985, novembro 11). Lei 18.454. Recuperado de https://www.leychile.cl/

Chile. Gobierno (2004). Informe comisión privatizaciones. Valparaíso: Cámara de Diputados.

Chile. Gobierno (2005). Informe de la Comisión Investigadora encarregada de analizar presuntas irregularidades en las privatizaciones de empresas del Estado ocurridas con anterioridad al año 1990. Valparaíso: Cámara de Diputados.

Dorner, W. (1974). Reflexiones sobre el interés nacional. Memorial del Ejército de Chile, 67(381).

El transporte marítimo. (1980). Revista de Marina, 97(736).

Ferrer, A. (2008). La economía argentina: Desde sus orígenes hasta principios del siglo XXI. Buenos Aires: Fondo de Cultura Económica.

Fontaine, A. (1988). Los economistas y el presidente Pinochet-Memoria Chilena. Santiago: Zig-Zag. Recuperado de http://www.memoriachilena.gob.cl/602/w3-article-86234.html

Fuentes, V. (1982). La economía: Análisis de la situación económica del país y de las medidas correctivas adoptadas recientemente. Memorial del Ejército de Chile, 76(410).

Garrido, E., Castagneto, P., Mesina, V. e Rivera, E. (2006). Historia de la marina mercante chilena, 1541-2006. Valparaíso: Asociación Nacional de Armadores de Chile.

Gobierno, Chile (2005). Informe de la Comisión Investigadora encargada de analizar presuntas irregularidades en las privatizaciones de empresas del Estado ocurridas con anterioridad al año 1990. Valparaíso: Cámara de Diputados. 
Goularti Filho, A. (2014). Presença e ausência do Estado na trajetória da indústria da construção naval brasileira, 1959-1989. Nova Economia, 24(2), 445-470. DOI: 10.1590/0103$6351 / 1256$

Hadermann, J. (1981). Marina mercante y seguridad nacional. Revista de Marina, 98(743).

Hamilton, A. (1995). Relatorio sobre as manufaturas 1791. Rio de Janeiro: Solidariedade Iberoamerica.

List, G. F. (1986). Sistema nacional de economia política. São Paulo: Nova Cultural.

Los intereses marítimos (1980). Revista de Marina, 97(735).

Martin, C. (2005). ASMAR: su contribuición a la industria naval em Chile. Viña del Mar: 2005. Viña del Mar: Orgraf Impresores.

Martinic, M. (1995). Los armadores de Punta Arenas de 1870 a 1930. Revista de Marina, 2, $132-142$.

Mayol, A. y Ahumada, J. M. (2015). Economía política del fracaso: La falsa modernización del modelo neoliberal. Santiago: El Desconcierto.

Mazzeo, J. J. (1974). Reflexiones sobre seguridad nacional. Memorial del Ejército de Chile, 66(378).

Munita, H. (1945). El problema de los astilleros em Chile (Tesis de licenciatura). Universidad de Chile, Chile.

Naciones Unidas (2018). 50 years of Review of Maritime Transport, 1968-2018: Reflecting on the past, exploring the future (núm. UNCTAD/DTL/2018/1). Naciones Unidas. Recuperado de https://unctad.org/system/files/official-document/dtl2018d1_en.pdf

Nueva política de transporte marítimo (1974). Revista de Marina, 91(700).

Palet, F. (1975). La marina mercante nacional. Revista Marina, 9(708).

Pinto, A. (2018). Chile, un caso de desarrollo fustrado. Santiago de Chile: Universitaria.

Política marítima nacional (1980). Revista de Marina, 97(739).

Poulantzas, N. (1985). O Estado, o poder, o socialismo. Rio de Janeiro: Graal.

Unidad Popular (Chile) (1970). Programa básico de gobierno de la Unidad Popular. Santiago: Autor.

Valdivia, V. (2001). Estatismo y neoliberalismo: Un contrapunto militar. Chile, 1973-1979. Historia, 34, 167-226. DoI: 10.4067/S0717-71942001003400006

Varas, C. (1995). Cien años de Astillero Varadero más astral del mundo 1896-1996. Valparaíso: Victoria.

Wood, G. L. (1969). ASMAR: bases para la formulación de una política de astillero para Chile. Revista de Marina, 86(668). 